\title{
"Start-Up" in E-Learning Mode as a Basic Project of the Final Year of Entrepreneurship Education
}

\author{
https://doi.org/10.3991/ijet.v16i04.18085 \\ Zhi-Jiang Liu \\ GuangXi Normal University, Guilin, China \\ Marina Galichkina $\left({ }^{凶}\right)$ \\ State University of Management, Moscow, Russia \\ Marika18@mail.ru \\ Anastasia Kurilova \\ Togliatti State University, Togliatty, Russia \\ Svetlana Vlasova \\ Moscow Aviation Institute, Moscow, Russia
}

\begin{abstract}
The study discusses the main positive aspects of the implementation of start-up projects at universities. In the context of the migration of most of the businesses to the network, the most important skill of an entrepreneur is the ability to build an online business from the very first steps. The basis for this is the creation a start-up in e-learning mode. A sample of Hong Kong and Russian universities has been designed to compare the practices of e-learning in entrepreneurship. It has been confirmed that the introduction of start-ups in e-learning mode in the final year of entrepreneurship education positively affects the development of professional qualities of students both in online and off-line business and helps to better consolidate the material. In addition, based on the work done, a final year model of entrepreneurship education with e-learning has been proposed; it is based on 3 main components (the student as a generator of ideas; the mentor as necessary support, and information online channels as the main source of information) and is aimed at solidifying knowledge through the start-up project defense. The importance of the role of universities in this process has been proved and the idea of involving a business mentor in e-learning process to achieve a synergistic effect has been considered.
\end{abstract}

Keywords-Start-up, e-learning, higher education, business project, entrepreneurship

\section{Introduction}

It is known that Russia has been planning to legislatively introduce the possibility of developing start-up projects instead of defending a thesis since 2019 [1,2]. The first 
definition of "start-up" goes back to 1939 [3]; it has been relevant since that time. Now, this term is increasingly understood as a start-up IT-company or online business. This understanding was established due to the fact that opening such a business requires minimal investment or can be practically free and allows you to use a large number of free platforms, services and opportunities [4]. This can be regarded as a positive trend as start-ups create new jobs [5] and positively affect national GDP. Aleksina et al. [6] define this concept as a newly formed company or group of people with a special culture, focused on the search for the opportunities for a rapid life cycle. In addition, it develops and/or implements a new technology and/or a product under the conditions of increased uncertainty and risk in order to achieve the maximum growth through the use of a scalable business model (usually based on innovative technology and/or products). The most easily scalable models with minimal costs are produced by the online business revolution, thanks to which the number of new companies has increased significantly [7]. But for the competent use of the opening opportunities, a higher level of digital literacy is required than the average literate web user has [8]. Foreign economists, such as Graham [9] or Blank [10], do not make such clarifications. They believe that rapid growth is the main start-up feature and all other characteristics are its consequence.

The relevance of the study is emphasized by the successful examples of start-ups demonstrated by Apple, Amazon, and other companies, most of which either originated as an e-commerce phenomenon or are related to the IT field and are actively promoting e-learning as a guarantee of the future of business [4]. These projects made their founders famous and rich; this successfully affected the country's economy. Firstly, they significantly increased tax revenues to the state budget, improved the investment climate and brought a positive image to the country. Domestic students can also contribute to the economic development of Russia if they are given the opportunity to develop their professional competencies at university and rationally spend 5 years of study.

\subsection{Literature review}

The problem of the quality of entrepreneurship education is relevant not only in Russia, but also in all post-Soviet countries. Also, in all countries of the region, there is a lag in the implementation of digital learning and e-learning opportunities [11]. For example, Belarus is actively working on the introduction and improvement of the American concept of "University 3.0" [12]. According to this, higher educational institutions should use innovative teaching methods and materially encourage students to collaborate with the business community. The main emphasis is placed on the formation of students' business competencies, which includes digital competence as a component. The importance of such skills is also emphasized by Kuzminov et al. [13], who together with his colleagues indicates the need for students to develop critical thinking as one of the main skills of a successful entrepreneur. The authors of the study come to the same conclusions and present a set of basic components of the entrepreneurship course [14,15]. 
The importance of developing entrepreneurial competencies in the long term is presented in Markovic [16]. The lack of practical skills among students led to the fact that most start-ups could not operate for more than 2 years. The author believes that the solution to the problem is the introduction of compulsory business plan development as an educational task for Economics students, as well as the creation of online based and supported entrepreneurships graduated and post-graduated e-learning business incubators on the territory of universities. This will contribute to the entrepreneurial skills of students and increase their motivation.

The study of De Mattos and Salciuviene [17] of the relationship between the possession of higher education and the success of international alliances held by the entrepreneur presents interesting conclusions. The research revealed a significant negative correlation between the above-mentioned factors. The authors explain this by the fact that practical skills to close deals are more important for employers than a diploma of higher education.

The experience of Romania and Kazakhstan is of interest Epure et al. [18]. The peculiarity of their methods is the creation of a highly competitive environment. Romanian entrepreneurs invited more than 350 students (it is noteworthy that $50 \%$ of them were women) to take the SMART course, one half of which was practical. A significant part of the course was online training and skills related to online business. At the end of the course, the students had to present their own business projects. The cash prize was 40,000 euros. At the same time, there was another experiment, the "PROFIT" project. The 36 winners received 36,000 euros each to develop their ideas. The main condition was that the project should create at least 2 new jobs. Thus, business and government started their cooperation to solve two significant problems at once - overcoming unemployment and preventing brain drain.

The models of modern Russian education considered by Naumov and Konstantinova [19] confirm the fact that in domestic Russian education, there is some interaction between businesses and the university in the form of various business incubators, online services, technology parks, small innovative enterprises, centers for entrepreneurship development, etc.

It should be noted that the first practical attempts to replace thesis writing with the development of a startup have been made [20]. Thus, $10 \%$ of the accelerator program graduates took a risk and successfully defended their business projects. According to the research figures, the innovative intensive training allows students to develop entrepreneurial competencies partially online, as well as the personal ones and find investors among mentors and experts. We should also note that the results obtained seem even more positive against the background of the unsuccessful experience of other countries. For example, the analysis of the 3 leading business schools in Egypt revealed that they had problems associated with the introduction of a similar methodology [21].

From a practical perspective, it will be feasible to study the experience of creating business incubators for startups in the corporate environment [22,23]. This example is unique; it demonstrates that domestic entrepreneurs are also interested in the provision of material incentives to the younger generation. They understand that one of the main elements of innovative development is the creation and promotion of startups. 
The creation of favorable environment represented by business accelerators is the key to the motivation to increase spending and promote their growth and development.

Moreover, a start-up can be an excellent option for updating entrepreneurial competencies not only among students, but also among schoolchildren. This can be proved by the project aimed at the development of continuous agribusiness education in rural areas of the Irkutsk region [24]. The project participants have been presenting their start-ups in various competitions for several years and they have won prestigious grants. In addition, the active interest of young people in improving agricultural technologies forms the belief that it can be highly profitable. Schoolchildren become carriers of advanced agricultural technologies; this will promote the latest agricultural developments in the near future. Similar projects in many countries use online learning and the formation of a start-up project by schoolchildren in a digital online environment, which is much more natural for children born in a digital environment [8].

Let us discuss more technological sectors, for example, heavy industry [25]. In this sector, employers are most often dissatisfied with the quality of modern education. The main complaint is associated with the inconsistency of the educational content with the requirements of high-tech real production. Continuous improvement of technologies requires updating of knowledge, which is effectively implemented by various forms of e-learning. Most of all managers appreciate competitiveness and stress resistance - the core competencies needed to create one's own project [26].

\subsection{Setting objectives}

The main purpose of the study is to confirm the positive impact of replacing a diploma defense practice with the development of a business project on base of elearning. Successful practical examples of such practices dating back to the 1990s along with the fact that this idea is not revolutionary in the world support modernizing academic education in this way. The most modern part of this idea is the preparation of the graduation project in e-learning mode.

Based on this, the immediate research tasks are:

- To determine the role of universities in the innovative development of higher education and the economy as a whole;

- To track the existing experience of similar practices in domestic and foreign universities;

- To compare the facts obtained to derive the optimal relationship between business and university culture;

- To offer our own model for designing the final year of entrepreneurial education in e-learning mode with the student project defense. 


\section{Methods and Materials}

To achieve the goal of the study, it was decided to analyze several leading universities, which had already implemented such innovative solutions. The research sample is presented below (Table 1):

Table 1. Universities Participating in the Study

\begin{tabular}{|c|c|c|c|c|}
\hline No. & University & $\begin{array}{c}\text { Program } \\
\text { years }\end{array}$ & $\begin{array}{l}\text { Sphere of business the pro- } \\
\text { gram was used in }\end{array}$ & $\begin{array}{l}\text { University } \\
\text { subdivision }\end{array}$ \\
\hline 1 & $\begin{array}{l}\text { Far Eastern Federal } \\
\text { University }\end{array}$ & 2016-2019 & $\begin{array}{l}\text { Economic and management } \\
\text { specialties }\end{array}$ & $\begin{array}{l}\text { School of Economics and } \\
\text { Management }\end{array}$ \\
\hline 2 & $\begin{array}{l}\text { Tomsk Polytechnic } \\
\text { University }\end{array}$ & Since 2019 & $\begin{array}{l}\text { Finance and Economic special- } \\
\text { ties }\end{array}$ & $\begin{array}{l}\text { School of Engineering Entre- } \\
\text { preneurship }\end{array}$ \\
\hline 3 & $\begin{array}{l}\text { Saint Petersburg State } \\
\text { University }\end{array}$ & 2011-2019 & Any specialty & $\begin{array}{l}\text { "Start-up at St. Petersburg } \\
\text { University" }\end{array}$ \\
\hline 4 & $\begin{array}{l}\text { Russian Economic } \\
\text { University named after } \\
\text { G.V.Plekhanov } \\
\end{array}$ & $\begin{array}{c}1907, \\
1990-2019\end{array}$ & $\begin{array}{l}\text { Economic and management } \\
\text { specialties }\end{array}$ & Business faculty "Captains" \\
\hline 5 & $\begin{array}{l}\text { Lomonosov Moscow } \\
\text { State University }\end{array}$ & The 1990s & Journalism & $\begin{array}{l}\text { The faculty of "Journalism" } \\
\text { (the concept of creative diplo- } \\
\text { ma) }\end{array}$ \\
\hline 6 & $\begin{array}{l}\text { Astrakhan State Tech- } \\
\text { nical University }\end{array}$ & 2016-2019 & marine technologies & $\begin{array}{l}\text { Russian Maritime Register of } \\
\text { Shipping (Astrakhan branch) }\end{array}$ \\
\hline 7 & $\begin{array}{l}\text { Hong Kong Baptist } \\
\text { University (China) }\end{array}$ & 1994-2019 & $\begin{array}{l}\text { Management, entrepreneurship, } \\
\text { finance, marketing, project } \\
\text { management }\end{array}$ & MBA \\
\hline
\end{tabular}

Source: Own development based on [27-29].

All British and American MBA programs are similar to each other. Thus, we highlighted one example in order to compare it with the Russian attempts. Hong Kong Baptist University was chosen as its program years coincide with the ones of Russian universities and its strong international flavour, which positively affects the accuracy of the results obtained.

All universities used the general scheme of electronic education at the stage of project preparation. It included the use of a single member account to integrate the services used; application of cloud storage services for integrated access to all project materials anywhere and from any mobile device; communication and consulting support of the teacher using social networks and instant messengers of the participant's choice; access to teaching materials, statistical and other data through the teacher's accounts in scientific-metric databases and in Western universities. Also, students could integrate into this environment those browser, computer and mobile applications that they considered necessary. E-learning had the advantage of freeing up the graduate's time to prepare the project at his own pace, while still allowing the teacher to maintain control over the progress of the project.

A more detailed description of each university will be presented in the "Results" section. Now let us discuss the main points. It is believed that the Far Eastern Federal University along with its School of Economics and Management were the first Russian university to offer students a choice between traditional diploma defence and an 
innovative start-up project [27]. However, this is not true. Few are aware that the socalled concept of "creative diploma" existed at the Faculty of Journalism at Moscow State University: students completed creative tasks instead of writing a diploma. The procedure was very similar to the development of a modern startup [28]. Nevertheless, there is some data on earlier attempts to introduce a practical component in business education in Russia. Thus, a similar practice has been used at Plekhanov Russian University of Economics for more than a hundred years. It was resumed in the 1990s when the educational programs that prepared entrepreneurs for a market economy started to appear [29].

To confirm the positive impact of a start-up project on consolidating professional competencies of students, a structural-functional research scheme was drawn up (Fig. $1)$ :

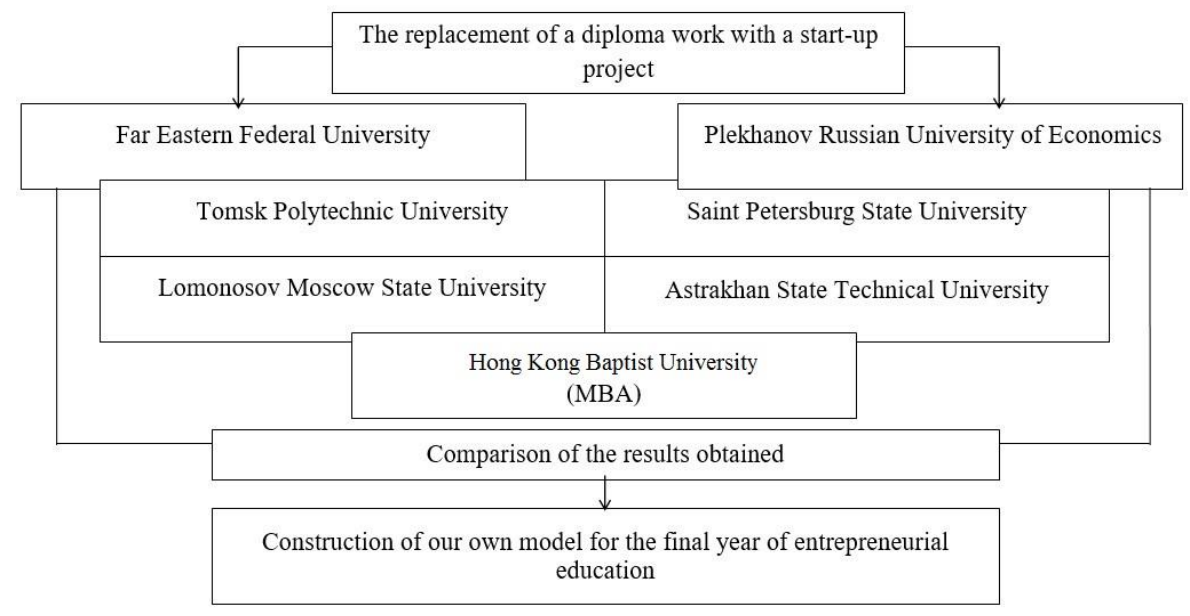

Fig. 1. Structural-functional research scheme

\section{Results}

Having analyzed the universities that have implemented innovative methods of developing start-up projects in e-learning mode as a diploma thesis (Table 1), we highlighted the following features:

- In other countries, this practice is often used in the framework of the following courses: "Management", "Economics", "Business" and related specialties. In Russia, the practice has been used in a variety of spheres, from journalism to marine technology, for such a short period of the existence of such structures;

- Each of the analyzed structures interpreted foreign standards in its own way, while in Hong Kong the previously invented British education model was followed. 
This suggests that the world practice is losing its relevance in realities and requires adjustments taking into account national characteristics. In this regard, we decided to present our own model for designing the final year of entrepreneurship education based on the developments by Chepurenko [30].

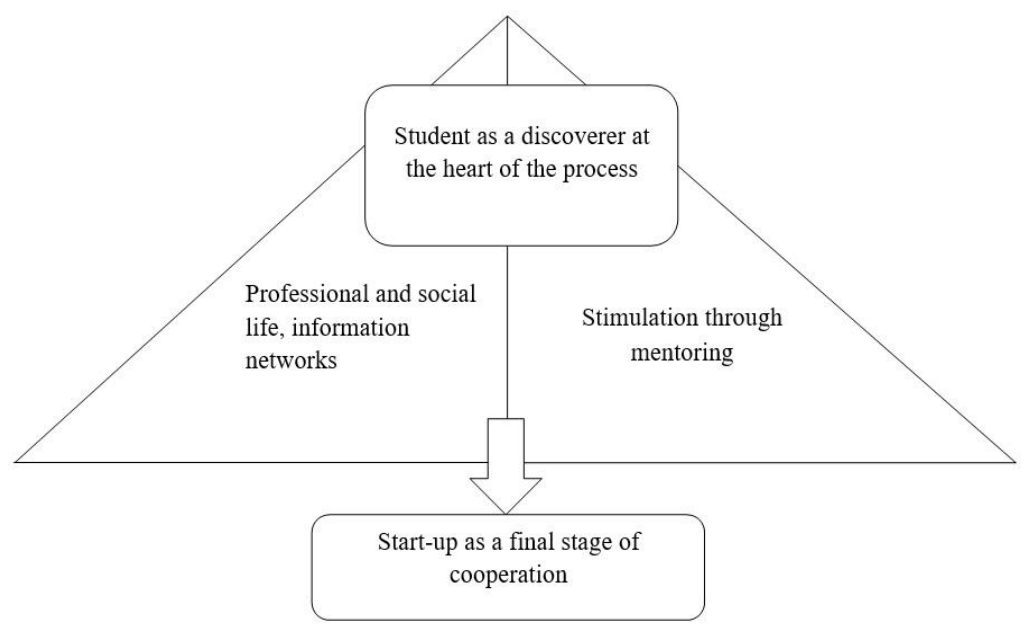

Fig. 2. The model of the final year of entrepreneurship education

The point is that the presented model will ensure the synergistic effect of student skills and aspirations through a combination of professional mentor support and the creation of the necessary information field. This model more naturally includes the components of e-learning and the use of the digital environment through the student's own search activity and online and mobile control and motivation from the mentor (Fig. 2). The result is a viable business model.

The student is at the heart of the process and is the main source of innovation and an idea generator. The role of the teacher shifts from total control and single expert opinion to more loyal mentor support. Traditional lectures also fade into insignificance giving way to practical actions and online tuition and mobile consulting. An important role is played by the digital environment, namely its flexibility and diversity. Learning objectives are not discussed in advance, but are formed in the learning process. Each topic gradually brings the student closer to the "start-up" basis; it shapes and structures the student's idea. Now let us discuss in more detail each of the topics.

Topic 1. Start-up creation. The importance of the idea in future business success.

At the initial stage, one should decide on the main task of the start-up and answer the 3 questions: "What are we doing? ", "Why?" and "For whom?". Correct wording is very important; thus, working with a mentor should take up most of the time. This is a period of discussion and debate, the use of "brainstorming" and other qualitative methods of information analyses, which will subsequently turn into a full-fledged business project. 
Topic 2. Start-up structure. Building an organizational structural structure.

It is very important to determine the rights and responsibilities of each project participant and create the so-called "employee's handbook" before detailing the idea. This will help to avoid unnecessary difficulties in the future.

Topic 3. Start-up essence. Product/service development.

When all the questions are answered and the roles are discussed, the prototype development should take place. The qualitative work at this stage will help to attract investors as at the final presentation they will be able to directly get acquainted with the proposed product (if this is possible). This stage is almost entirely carried out using online services and online communication with a mentor, teachers and investors.

Topic 4. Start-up promotion. Marketing strategy development.

The collaboration with contact audiences should take place at this stage. A potential buyer is the one who can assess the quality of the product. The study of the target audience will provide information on the best product/service promotion tactics and the tools to be used, etc.

Topic 5. Start-up defense. Final presentation.

We believe that visual presentation is crucial when introducing the product to investors. Technical skills for preparing presentations will be an excellent addition to the set of core business competencies. In addition, this will positively affect the student's competitiveness when entering the labor market.

\section{Discussion}

The methodology is relatively new and there are still very few theoretical developments with practical analysis.

Among those developments, the work by Shtikhno and Iskandaryan [31] should be highlighted. He describes the activities of the specialized Business faculty of St. Petersburg State University, "Captains", and notes their positive and negative aspects. $\mathrm{He}$ also considers the experience of other Russian universities; however, he does not provide any comparative analogies and indicates only facts.

Another significant study is the manuscript by Zemlina [20] devoted to the formation of entrepreneurial competencies of the Southern Federal University students. The results of the study confirm our thesis that students are ready and want to implement their business ideas within the university $(70 \%$ of the respondents chose this option in the questionnaire). But at the same time, it allows us to highlight a negative tendency that students make a decision to "postpone" bringing their startup to the real market. This is evidenced by the percentage of positive answers (11\%); the indicator is not high, but it significantly higher than the international one [20]. Western researchers suggest that the optimal solution to this problem is to use e-learning elements that increase student motivation and engagement. More intense contact with the teacher in a familiar digital environment increases student loyalty and pleasure from participating in the training and in the project, and also solves the problem of "postponement" [32]. 
From a practical perspective, the work by Otkidysheva [33] is interesting; it proves that mentoring is the main way to improve the skills of specialists. In addition, she believes that student startups developed on the basis of the university are more likely to succeed if they are developed under the supervision of experienced domain specialists. Foreign studies, even in the case of promoting the need to develop specialized software systems for training entrepreneurs online, confirm the importance of contact with a mentor and an experienced business mentor [34].

The next group of researchers went even further and conducted an experiment that involved university employees in writing startups [35]. To prove that teachers have not lost touch to generate innovative ideas, they were invited to participate in the competition together with their students. As a result, a total of 92 high-quality works, which describe the development and implementation of a startup, were received. What is noteworthy, IT start-ups were the most common, that is, projects related to information technologies.

Researchers point out that the vast majority of start-ups, especially those that survive the first two years and continue profitable activities, are closely related to IT and the online business $[4,8]$.

It should be noted that in the university context, start-up is a project in the elearning mode, on the basis of which the above-mentioned organization is created. The use of such tools strengthens the role of universities in developing the innovative potential of the country $[11,36,37]$. To confirm this, let us present the statistics from the National Report GUESSS (Global University Entrepreneurial Spirit Students' Survey) [38]. It is traditionally acknowledged that students better perceive various innovations and demonstrate dynamic growth. They are active and ambitious people who have huge intellectual and physical potential, which should be used to restore a stable economic situation in the country. The state bank on future entrepreneurs. The lack of the necessary environment at the university can negatively affect the entrepreneurial potential of students and postpone their business activities until they get working experience. The presence of an appropriate online environment in this case can correct the situation or form an additional bonus in achieving academic efficiency and motivation in the future business activity [7]. According to the international data [38], Russian universities demonstrate a lower involvement of students in the creation and implementation of the disciplines and entrepreneurship programs in the educational process compared to other countries. In addition, Mutalimov et al. [39] highlights the development of the following professional competencies with the help of startup projects: marketing research; pricing; financial planning; business planning and modeling; company registration; financial controlling; corporate management; tax management and accounting; risk management. Also, we suppose that such approach to education develops personal qualities of students, such as: desire for personal development; leadership; creativity; initiative; self-confidence; risk tolerance, determination, self-motivation; resoluteness; flexibility.

Western researchers emphasize the use of certain types of technology, in particular, pointing out that technology serves as a mediator between content and the experience of the teacher and mentor and student. Such mediation turns out to be more effective 
for new generations of students accustomed to the presence of electronic communication channels as a universal mediator $[32,40]$.

In the GUESSS survey, the students were also asked to evaluate the effect of the university atmosphere on supporting and developing their entrepreneurial activities. Everyone is familiar with the vivid examples of Stanford University, Harvard University and the Massachusetts Institute of Technology; they have managed to create a sustainable entrepreneurial environment which later turns into a strong corporate spirit. Nevertheless, the results obtained give hope for further improvements: 4.51 out of 7 , compared to the world average of 4.43 points [38].

\section{Conclusion}

In the course of the study, we have concluded that the development of a start-up project in the e-learning mode has a positive effect on the improvement of students' professional competencies. The importance of the role of universities in this process has been proved and the idea of involving a business mentor online to achieve a synergistic effect has been considered.

We should also highlight the fact that this practice of e-learning experience is most popular among economic and managerial specialties compared to the financial or technical ones. It was found that a unique practice of defending a creative diploma after thesis was implemented by Moscow State University at the Faculty of journalism in the 1990s. Today there is no such practice.

A sample of the universities that showed the most striking results in implementing business e-learning experienced projects was formed. Hong Kong Baptist University and its basic MBA program were compared with the practices of Russian universities. The selection criterion was based on the similarity of the indicators. As a result, interesting findings were obtained: while the whole world uses this methodology to train economists and managers in digital environment, Russia uses it in non-standard areas, increasing the effectiveness of technical specialties.

Based on the work done, we have developed our own model of use elements of elearning in the final year of entrepreneurial education; it is based on 3 main components: the student as a generator of ideas; the mentor as necessary support, and information channels as the main source of information.

\section{Acknowledgement}

Zhi-Jiang Liu was supported by University-Industry Collaborative Education Program of Ministry of Education (2020): Research on the Construction of Practical Teaching System for the Cultivation of Applied Talents in Human Resource Management Specialty; Research on the Construction of Cross-border E-commerce Training Base for China-Asean Cooperation;The Project ofImproving the Basic Scientific Research Ability of Young and Middle-aged Teachers in Guangxi Universities: "Research on the Innovation of Artificial Intelligence Enterprises in the 5G Era". 


\section{$7 \quad$ References}

[1] Bubnova, I.A., Kazachenko, O.V., Tokareva, E.A. (2019). Declaration of values in orders and medals: historical aspect. Sociological studies, 11: 131-139.

[2] Education in Russia (2019). Both a diploma thesis and a start-up: students will graduate from universities with developed business projects. Telegraph news. https://russiaedu.ru/ article/i-diplom-i-startap-iz-vuzov-budut-vypuskat-s-gotovymi-biznes-proektami

[3] Jauhiainen, M. (2016). Beyond the hype: a discursive study on the identity projects of early-stage startup entrepreneurs. Aalto University, Markkinoinnin laitos.

[4] Kohavi, R., Thomke, S. (2017). The Surprising Power of Online Experiments: Getting the Most Out of A/B and Other Controlled Tests. Harvard Business Review, 95(5): 74-82.

[5] European Commission (2016). Europe's Next Leaders: The Start-up and Scale-up Initiative. http://ec.europa.eu/transparency/regdoc/rep/1/2016/EN/COM-2016-733-F1-EN-MA $\underline{\text { IN.PDF }}$

[6] Aleksina, A.S., Khabirova, A.V., Glukhikh, P.L. (2019). Youth start-up movement: the analysis of foreign theoretical approaches. Journal of Economic Theory, 16(2): 234-248

[7] Hua, S., Ren, Z. (2020). "Online+ Offline" Course Teaching Based on Case Teaching Method: A Case Study of Entrepreneurship Education Course. International Journal of Emerging Technologies in Learning, 15(10): 69-85. https://doi.org/10.3991/ijet.v15i10.139 $\underline{99}$

[8] Ngo, L., Tyrell, S., Volkov, M., Bridson, K. (2018). Embedding digital literacy: Towards transforming business education. In 35th International Conference of Innovation, Practice and Research in the use of Educational Technologies in Tertiary Education Learning Without Borders, Open Oceans, pp. 466-472.

[9] Graham, P. (2012). Startup equals growth. Graham's Essays on entrepreneurship. http://www.paulgraham.com/growth.html

[10] Blank, S. (2010). What's A Startup? First Principles. Steve Blank.

[11] Volegzhanina, I.S., Chusovlyanova, S.V., Adolf, V.A., Bykadorova, E.S., Belova, E.N. (2017). Knowledge management as an approach to learning and instructing sector university students in post-Soviet professional education. Journal of Social Studies Education Research, 8(2): 39-61. https://doi.org/10.17499/jsser.360863

[12] Minister of Education of the Republic of Belarus (2017). On improving the activities of higher educational institutions on the basis of the University 3.0 model. National legal informormation center. The Republic of Belarus, Minsk.

[13] Kuzminov, Y., Sorokin, P., Froumin, I. (2019). Generic and specific skills as components of human capital: New challenges for education theory and practice. Foresight and STI Governance, 13(2): 19-41. https://doi.org/10.17323/2500-2597.2019.2.19.41

[14] Efimov, O., Ableeva, A., Salimova, G., Kovshov, V., Putyatinskaya, Y., Siraeva, R., Faizov, N. (2019). The Concept "Service": Its Essence in the Entrepreneurship Economy and its Place in Business Education. Journal of Entrepreneurship Education, 22(2): 1-16.

[15] Ustyuzhina, O., Mikhaylova, A., Abdimomynova, A. (2019). Entrepreneurial competencies in higher education. Journal of Entrepreneurship Education, 22(1): 1-14.

[16] Markovic, A. (2019). Leadership Qualities and Differences Required for Business Startups in Serbia. Doctoral dissertation, The College of St. Scholastica.

[17] De Mattos, C., Salciuviene, L. (2019). The negative influence of the entrepreneur's level of higher education on the attractiveness of European SMEs as alliance partners in Brazil: the role of practical experience and international entrepreneurial orientation. The International Journal of Human Resource Management, 30(13): 1997-2025. https://doi.org/10.1080/095 $\underline{85192.2017 .1316758}$ 
[18] Epure, M., Sutbayeva, R., Kosmaganbetova, G. (2019). Entrepreneurship Education: Innovation and Creativity. CESBA $5^{\text {th }}$ International Conference on Economic Sciences and Business Administration "The Future of Business". Premium Wellness Institute, Bucharest, Romania.

[19] Naumov, S.Yu., Konstantinova, L.V. (2019). The formation of a system of continuous business education: problems and solutions. Higher Education in Russia, 28(3): 137-146.

[20] Zemlina, E.M. (2019). The development of entrepreneurial competencies of Southern Federal University students. Concept, 10: 26-36.

[21] Mousa, M., Abdelgaffar, H.A., Ayoubi, R.M. (2019). Responsible management education in Egyptian public business schools. Journal of Management Development, 38(8): 681696. https://doi.org/10.1108/jmd-01-2019-0022

[22] Abdimomynova, A., Kolpak, E., Doskaliyeva, B., Stepanova, D., Prasolov, V. (2019). Agricultural diversification in low-and middle-income countries: Impact on food security. Montenegrin Journal of Economics, 15(3): 167-178. https://doi.org/10.14254/1800-5845/ 2019.15-3.12

[23] Danshina, V.V. (2019). Algorithm for Corporate Startup Accelerator Implementation. In International Scientific Conference" Far East Con"(ISCFEC 2018). Atlantis Press, pp. 703708. https://doi.org/10.2991/iscfec-18.2019.159

[24] Nemirich, T.N. (2019). Social partnership between the school and the board of trustees as a means of pre-vocational training of entrepreneurial students in the conditions of agribusiness. CredeExperto: transport, society, education, language, 1: 226-236.

[25] Matveeva, A.S. (2019). The role of higher education in ensuring sustainable development of the economy of industry. View of young scientists on the problems of sustainable development, 40: 234-244.

[26] Panfilova, E., Dzenzeliuk, N., Domnina, O., Morgunova, N., Zatsarinnaya, E. (2020). The Impact of Cost Allocation on Key Decisions of Supply Chain Participants. International Journal of Supply Chain Management, 9(1): 552-558.

[27] EHB (2018) No more diploma theses, go straight to business. https://novostivl.ru/msg/262 $\underline{42 . h t m}$

[28] Shtykhno, D. (2019). University degree thanks to a start-up project: how to help a student become a businessman. Analytics of Plekhanov Russian university of Economics. https://analitica.rea.ru/article/obrazovanie-i-kadry/diplom-za-startap-kak-pomoch-studentu -stat-biznesmenom/

[29] University Book (2019). Students at St. Petersburg State University will be able to defend a start-up project instead of a diploma thesis. http://www.unkniga.ru/company-news/9046studenty-spbgu-smogut-pomenyat-zaschitu-diploma-na-zaschitu-proekta.html

[30] Chepurenko, A.Yu. (2017). The methods and reasons to teach students entrepreneurship. Educational Studies Moscow, 3: 250-276.

[31] Shtykhno, D.A., Iskandaryan, R.A. (2019). Student start-ups as a tool for developing entrepreneurial skills. Economics: yesterday, today, tomorrow, 9(2A): 252-262.

[32] Pham, L., Limbu, Y.B., Bui, T.K., Nguyen, H.T., Pham, H.T. (2019). Does e-learning service quality influence e-learning student satisfaction and loyalty? Evidence from Vietnam. International Journal of Educational Technology in Higher Education, 16(1): 7. https://doi. $\underline{\text { org/10.1186/s41239-019-0136-3 }}$

[33] Otkidysheva, A.V. (2015). The potential of start-up mentor in the education and advanced training of specialists. Student Search, 2(26): 144-148.

[34] Ji, X. (2017). Development and Application of Computer-Aided Innovative Learning Mode of Undergraduate Entrepreneurship. International Journal of Emerging Technologies in Learning, 12(01): 155-167. https://doi.org/10.3991/ijet.v12i01.6171 
[35] Akhmetshin, E.M., Pavlyuk, A.V., Ling, V.V., Mikhailova, M.V., Shichiyakh, R.A., Kozachek, A.V. (2019). The use of private start-ups in higher education. Journal of Entrepreneurship Education, 22(1S): 1-12.

[36] Afonasova, M.A., Panfilova, E.E., Galichkina, M.A. (2018). Social and economic background of digital economy: conditions for transition. European Research Studies, 21(3): 292-302.

[37] Smirnova, Y.V., Nabokina, M.E. (2019). Evolution of social thinking of soviet researchers and ideological politics. In The European Proceedings of Social \& Behavioural Sciences EpSBS, pp. 1399-1405. https://doi.org/10.15405/epsbs.2019.03.02.162

[38] Shirokova, G.V., Bogatyreva, K.., Beliaeva, T.V., Tsukanova, T.V., Laskovaia, A.K. (2018). Global University Entrepreneurial Spirit Students' Survey: The National Report (Russia). http://www.guesssurvey.org/resources/nat_2018/GUESSS_Report_2018_Russia. pdf

[39] Mutalimov, V., Volkovitckaia, G., Buymov, A., Syzdykov, S., Stepanova, D. (2020). Entrepreneurship education: Start-up as a tool for actualizing students' professional competencies. Journal of Entrepreneurship Education, 23(1): 1-13.

[40] Sudarwati, N. (2018). Evaluating E-Learning as a Learning Media: A Case of Entrepreneurship E-Learning Using Schoology as Media. International Journal of Emerging Technologies in Learning, 13(09): 269-279. https://doi.org/10.3991/ijet.v13i09.7783

\section{Authors}

Liu Zhi-Jiang - School of Economics and Management, GuangXi Normal University, Guilin, China.

Galichkina Marina Alexandrovna is a $\mathrm{PhD}$ in Economics, Associate Professor of the Department of Organization Management in Machinery Industry, State University of Management, Moscow, Russia.

Kurilova Anastasia Alexandrovna is a $\mathrm{PhD}$ in Economics, Professor of the Department of Finance and Credit, Togliatti State University, Togliatty, Russia.

Vlasova Svetlana Viktorovna is a Senior Teacher of the Department of I-11 Foreign Language for Aerospace Specialties, Moscow Aviation Institute, Moscow, Russia.

Article submitted 2020-08-27. Resubmitted 2020-10-26. Final acceptance 2020-10-26. Final version published as submitted by the authors 